\title{
COMPARATION STUDY OF THE USE NAFTALENA FROM COAL TAR WASTE WITH CAMPER NAPHTALENE AS CONCRETE ADMIXTURE
}

\author{
Sumarno, AGUNG \\ Faculty of Engineering, University Mercu Buana Jakarta, Indonesia \\ Agung.ayahshofiyya@gmail.com \\ Syafwandi \\ Faculty of Engineering, University Mercu Buana Jakarta, Indonesia \\ Adelia Rizky, FATMAWATI \\ Faculty of Engineering, University Mercu Buana Jakarta, Indonesia \\ Adelialia207@gmail.com \\ Sumiyati \\ Faculty of Administration, University Mercu Buana Jakarta, Indonesia \\ Sumi.widi@gmail.com
}

\begin{abstract}
Concrete is a mixture of Portland cement or other hydraulic cement, fine aggregate, coarse aggregate, and water, with or without additives (admixture).

The naphthalene superplasticizer used comes from distillation of coal tar and a little from the rest of petroleum, but there is also camphor naphthalene. Where camphor grains contain $250-500 \mathrm{mg}$ of naphthalene. Naphthalene is mostly produced from coal tar distillation, and a little from the rest of the fractionation of petroleum, by the molecular formula $(\mathrm{C} 1 \mathrm{HH} 8)$ and in the form of two unified benzene rings. This compound is volatile, volatile even in the form of solids. The vapor produced is flammable.

The purpose of this study was to determine the effect of the use of naphthalene from coal tar waste with camphor naphthalene as concrete admixture, and determine the effect of naphthalene from coal tar waste with camphor naphthalene on concrete toughness, density, water absorption, of concrete compressive strength. It is expected that the use of naphthalene can reduce the use of cement, and reduce water use. But it does not reduce the strength of the concrete so as to reduce costs in making concrete. The variations in the use of camphor naphthalene and coal tar naphthalene are $20 \%, 30 \%, 40 \%$.
\end{abstract}

Keywords : Naphthalene coal tar, Naphthalene camphor, Compressive strength.

\section{INTRODUCTION}

In the world of civil construction, concrete is generally used as construction material in structures. Concrete is a mixture of Portland cement or other hydraulic cement, fine aggregate, coarse aggregate, and water, with or without additives (admixture). As we age, the concrete will harden and will reach the strength of the plan (fc ') at 28 days. Concrete has good compressive strength, therefore concrete is widely used or used for the selection of types of structures, especially structures, bridges and roads. (SNI 28472013: 17). The increasing development in the construction sector is very influential on the existing concrete technology, its use is indeed very high in terms of cost, selection of good quality materials, with good compressive strength in concrete and reduce the risk of damage or porous concrete. As is known, that in cement production contributes to global warming due to $\mathrm{CO} 2$ emissions which are quite large. In increasing the amount of cement used in the manufacture of concrete it will cause an increase in global warming, 


\section{Volume 03 Number 02 Maret 2020}

but for the use of Portland cement itself will continuously cause the basic material for making cement itself will be depleted (Simatupang, et al, 2016: 140).

Therefore, a lot of research to find alternative materials that can reduce the use of cement. There are several methods used to reduce the use of cement, and reduce the use of water but will not reduce the strength in concrete is to provide added material. Materials added to concrete mixes are usually used to modify the properties and characteristics of concrete such as using superplasticizer as admixture of concrete, in addition to being easy to do and saving costs. And use a mixture of materials for making concrete with waste that is no longer utilized and is environmentally friendly. And reduce costs when making concrete.

Previous studies using superplasticizer added ingredients namely Naphtalene and Polycarboxilate Additive to normal compressive strength, in this study the analysis was carried out to analyze the compressive strength of naphthalene and polycarboxilate superplasticizers compared to normal concrete without reducing the use of admixture mutubeton planned, with the addition of admixture by $1 \%$ of cement weight, and slump obtained $10 \pm 2 \mathrm{~cm}$. The results obtained from the use of naphthalene admixture can increase the compressive strength of concrete by $8.8 \mathrm{MPa}$ at 28 days of testing. The added ingredients in the use of admixture polycarboxilate when compared to the addition of naphthalene admixture, but it also can reduce water up to $40.98 \%$ for the use of polycarboxilate and $24.88 \%$ in the use of naphthalene admixture. (Nadia, et al, 2012: 39)

The naphtalene superplasticizer used mostly comes from distillation of coal tar, and a little from the rest of petroleum, but there is also naphthalene from camphor. Camphor is no longer a strange item in our lives, camphor has a very distinctive and sharp odor. Camphor contains a substance called naphthalene which is a compound. Where a camphor contains 250-500 mg of naphthalene. Naphthalene is an aromatic crystalline hydrocarbon in the form of a white solid with the formula naphthalene $(\mathrm{C} 10 \mathrm{H} 8)$ and in the form of two unified benzene rings. This compound is volatile, volatile even in the form of solids. The vapor produced is flammable. (Prasetyo, et al, 2015:3)

Therefore, it is interested to try to make a research on the comparison of the use of naphthalene from coal tar waste with camphor naphthalene as concrete admixture. With the hope of using camphor naphthalene, it can reduce the use of cement and reduce water, the price will be economical.

In this study offers that the incorporation and use of added materials such as camphor naphthalene and coal tar waste will be more practical in work, easy to apply (workability), good elasticity in concrete, the time of initial binding (setting time) in a gradual process will be good, the price materials needed for naphthalene camphor added ingredients are cheaper and economical prices, naphthalene camphor added ingredients are not hard to find, as well as saving costs when making concrete. The unit price of concrete will not be too expensive if the added material used is relatively economical and produces good quality concrete.

\section{METHODOLOGY}

The research method used in this thesis is an experimental method in a concrete laboratory. The experimental method is an experimental method used in studying the effect of a variable on other variables that function to improve the compressive strength and quality of concrete by providing added materials, one of which is the use of admixture. All processes or procedures in conducting this research refer to SNI (Indonesian National Standard).

Before carrying out the process of making concrete (mixing), the first thing we will do is prepare the materials that will be used for the concrete manufacturing process, such as testing the materials that will be used so that we know the quality and specifications for the use of these materials, and according to the specifications of the 
concrete we need. The process of testing materials such as testing an aggregate such as coarse (splite) and fine aggregate (sand) testing is often called (sieve analysis test) aims to find out the fineness of an aggregate, specific gravity aims to determine the specific gravity at an aggregate both fine and coarse aggregate, absorption (absorption) aims to determine the water content in an aggregate on a dry surface, the weight content (density), organic content of fine aggregates (organic Impurities for fine aggregates) aims to determine the levels of organic or impurities in the sand we are testing by mixing water and then we match the color of the water with a test tool that we normally use (Orbeco Analytical System, Inc.).

After all stages of the physical aggregate testing process is complete, then the process of designing and selecting materials that are suitable for the purpose of the concrete in accordance with certain specifications and strengths (mix design), when the process of designing a mixture on concrete is according to specifications we will do a trial of making fresh concrete usually the process stirring can use a mixer or with a manual stirring process, after the stirring process has been homogeneous or evenly distributed we are testing fresh concrete between other slump tests using abram cones and iron sticks or using flow test boards, aiming that we know the freshness of fresh concrete and making cylinder test sample.

This chapter explains the steps of slump test, concrete cylinder making, concrete compressive testing, density testing, water absorption testing. 


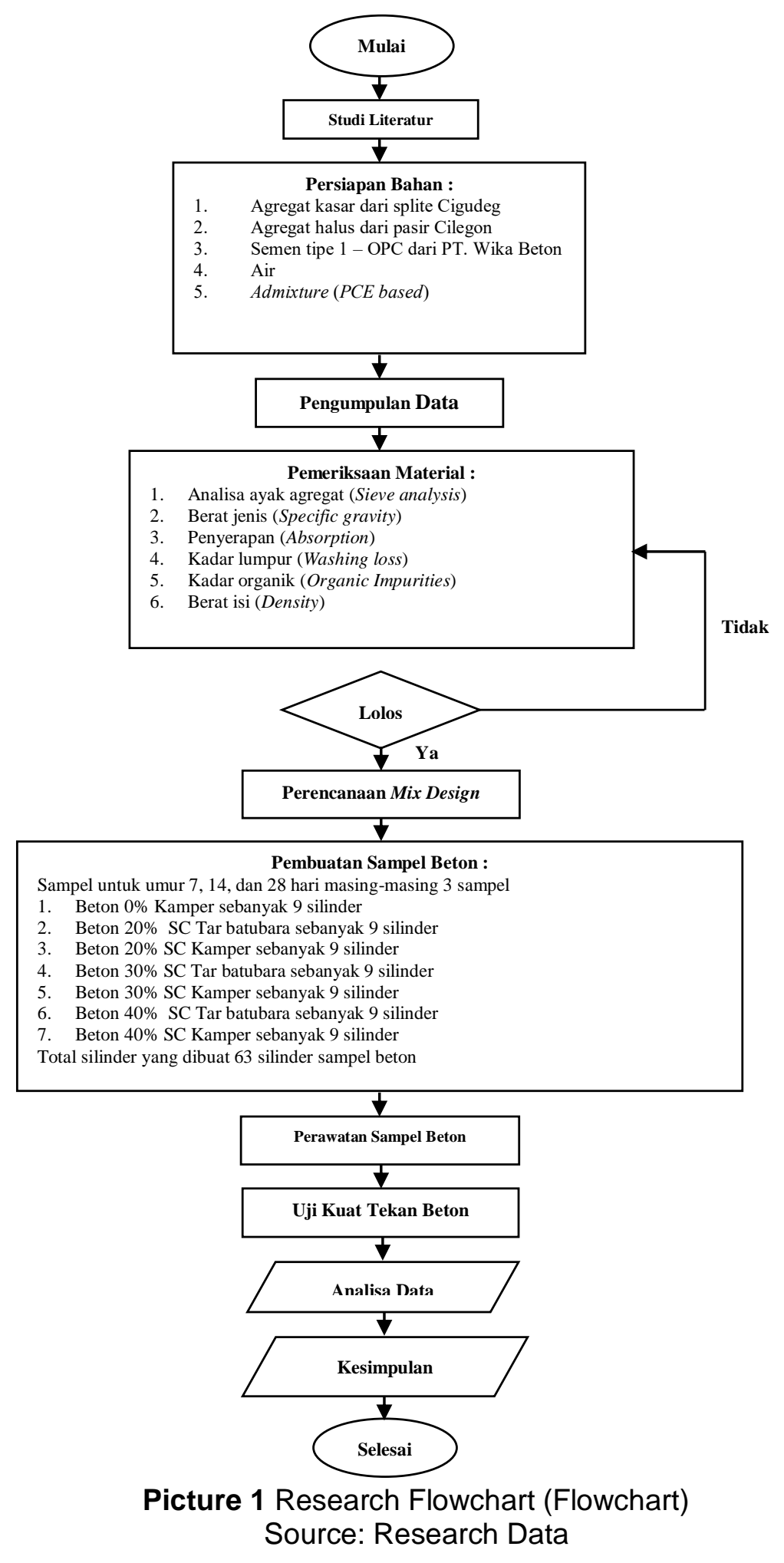

In this study the constituent materials in the concrete mixture are as follows:

a) Coal tar used comes from PT. Krakatau Steel

b) Cement used Type 1 - OPC from Wika Beton.

c) The coarse aggregate used originates from the Cigudeg splite, and the fine aggregate used 
Volume 03 Number 02 Maret 2020

\section{Galunggung sand received by PT. Wika Concrete CPB}

d) The water used comes from the Bor wells in the Gunung Putri - Bogor area

e) admixture materials used in concrete are Naphthalene camphor type superpartilizer andcoal tar naphthalene.

Table 1. Material Requirements for $1 \mathrm{~m}^{3}$

\begin{tabular}{lccccc}
\hline Material & Satuan & Mix 0\% & Mix 20\% & Mix 30\% & Mix 40\% \\
\hline Cement & $\mathrm{Kg}$ & 480 & 480 & 480 & 480 \\
Sand & $\mathrm{Kg}$ & 740 & 740 & 740 & 740 \\
Splite & $\mathrm{Kg}$ & 1065 & 1065 & 1065 & 1065 \\
Water & $\mathrm{Kg}$ & 90 & 90 & 90 & 90 \\
Coal Tar & $\mathrm{Kg}$ & - & 300 & 300 & 300 \\
Naphtalene & $\mathrm{Kg}$ & - & 400 & 300 & 200 \\
Ball & & & & & \\
\hline
\end{tabular}

The study was conducted as many as 7 variations namely control concrete, naphthalene with variations of $20 \%, 30 \%, 40 \%$ and naphthalene coal tar variations of $20 \%, 30 \%, 40 \%$ with a total concrete sample of 63 concrete samples.

\section{Place and time of research}

Where: This research will be conducted at PT Wika Beton Laboratory.

Timing: September 2019-January 2020

\section{Result And Analysis}

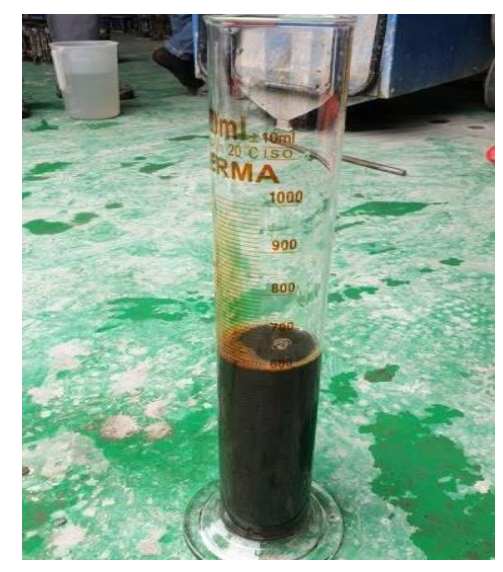

Picture 2. Coal Tar

\section{Source : Research Data}

Coal tar is a by-product of the carbonation process of coal or wood during gas production. Tar is liquid, dark in color, and has a strong odor. This material is sensitive to temperature changes. Tar contains toxic chemicals that are harmful to human health and the environment. Tar is a mixture of a solution of disperse wood smoke in water made by condensing pilorisi smoke. Tar can be produced from coconut shell pilorisis with a phenol content of $4.13 \%, 11.3 \%$ carbon, and 10.2\% acid. (Darmaji, 1998 in Raspati, et al, 2015: 664). 


\section{Volume 03 Number 02 Maret 2020}

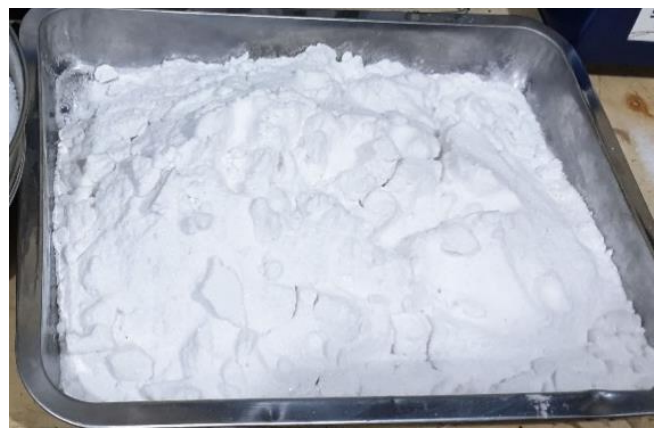

Picture 3 Naphtallene Ball

\section{Source : Research Data}

Camphor naphthalene contains $250-500 \mathrm{mg}$ of naphthalene. Naphthalene is mostly produced from distillation of coal tar, and a little from the rest of the fractionation of petroleum, by the molecular formula $(\mathrm{C} 10 \mathrm{H} 8)$ and in the form of two unified benzene rings. This compound is volatile, volatile even in the form of solids. The vapor produced is flammable. (Prasetyo, et al, 2015: 3)

\section{Slump Testing (Workability)}

Slump testing (workability) is needed to determine the level of fresh concrete permeability. The higher the value of the slump, the concrete is thinner and easier to do, and vice versa. In this study the researchers planned a slump valueof $10 \pm 2 \mathrm{~cm}$.

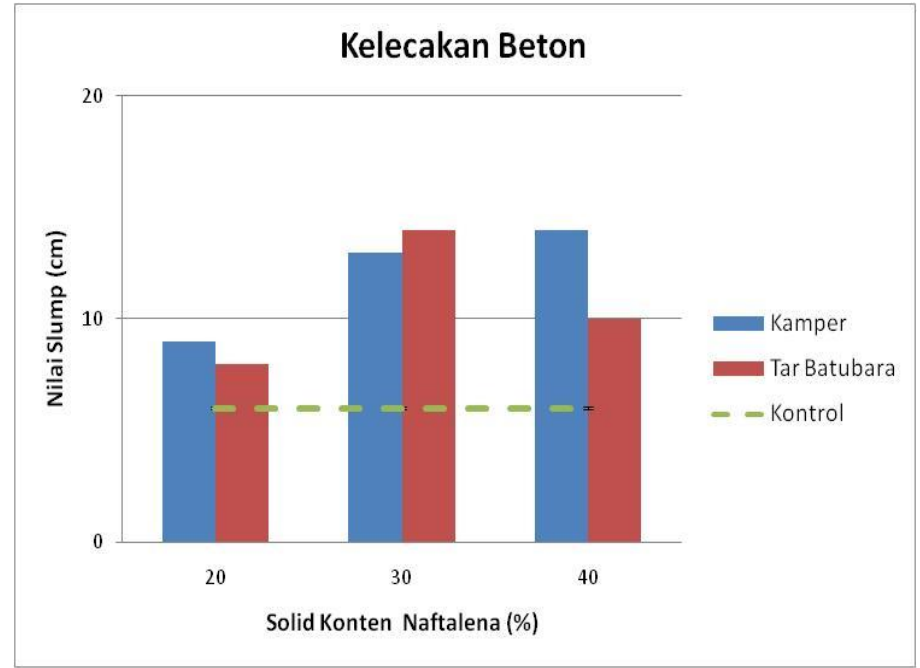

Picture 4 Slump Test Source : Research Data

In a linear trendline the concrete using camphor added material or coal tar will experience an increase in slump so that the concrete acceleration will be better which has an easy impact on the process. For the highest slump value in $40 \%$ camphor concrete and $30 \%$ coal tar concrete with $14 \mathrm{~cm}$ slump value.

\section{Concrete Density Test.}

Density (density) is a test of weight or volume weight, one of the benefits of testing the results can be used to calculate the weight on the structure or calculate the loading. 
Volume 03 Number 02 Maret 2020

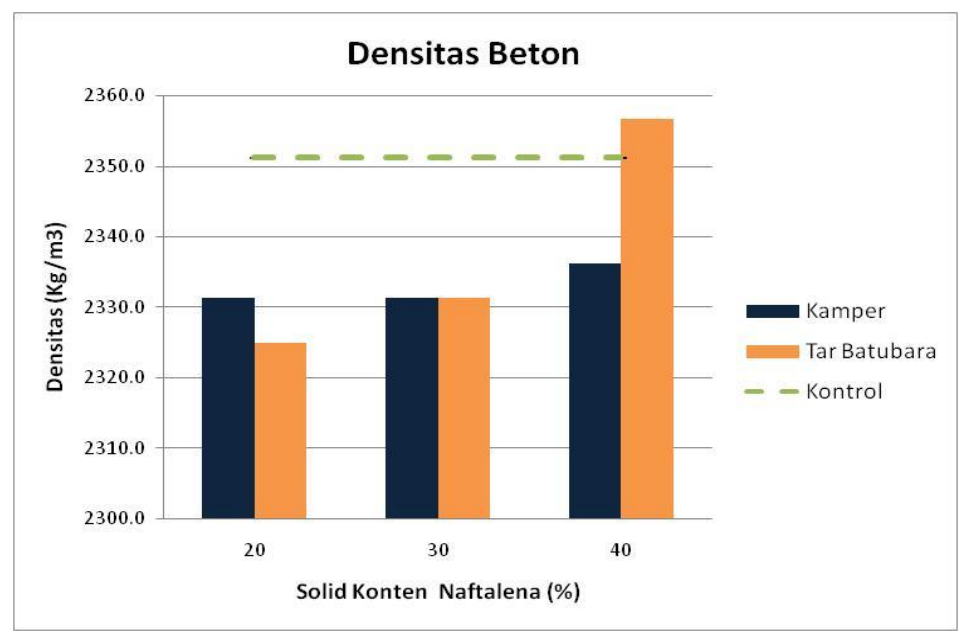

Picture 5 Density Concrete (Density)

Source : Research Data

Concrete has a density of $2200-2500 \mathrm{~kg} / \mathrm{m} 340 \%$ coal tar concrete has the highest density against other variations.

\section{Concrete Absorption Testing.}

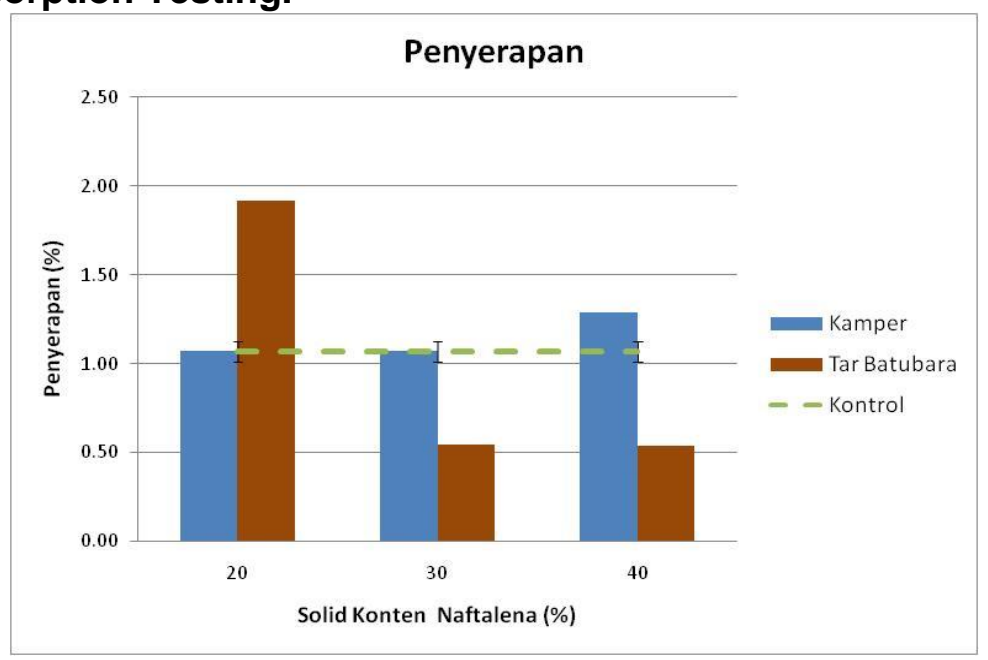

Picture 6 Absorption Concrete

Source : Research Data

Water Absorption Testing can find out what percentage of concrete can absorb water, for normal concrete conditions a smaller percentage of water absorption is better because the concrete can be waterproof so that if applied to the structure it can prevent water from entering so the reinforcing iron is not exposed to water making the structure durable and strong. In this research, the results of absorption of concrete using camphor the greater the percentage of camphor variation, the greater the absorption of concrete. The result of absorption of $40 \%$ camphor concrete variation has the greatest value of $1.29 \%$ of the other concrete.

The results of the absorption of concrete using $20 \%$ coal tar has the highest absorption of $1.92 \%$ compared to other coal tar variations and control concrete. 


\section{Concrete Compressive Strength Testing}

Concrete compressive strength testing is done by using a compressive test tool with 9 concrete samples per variation. 3 samples on days 7, 14, 28 other samples on day 28 . Following are the results of the 7-day-old concrete compressive strength test:

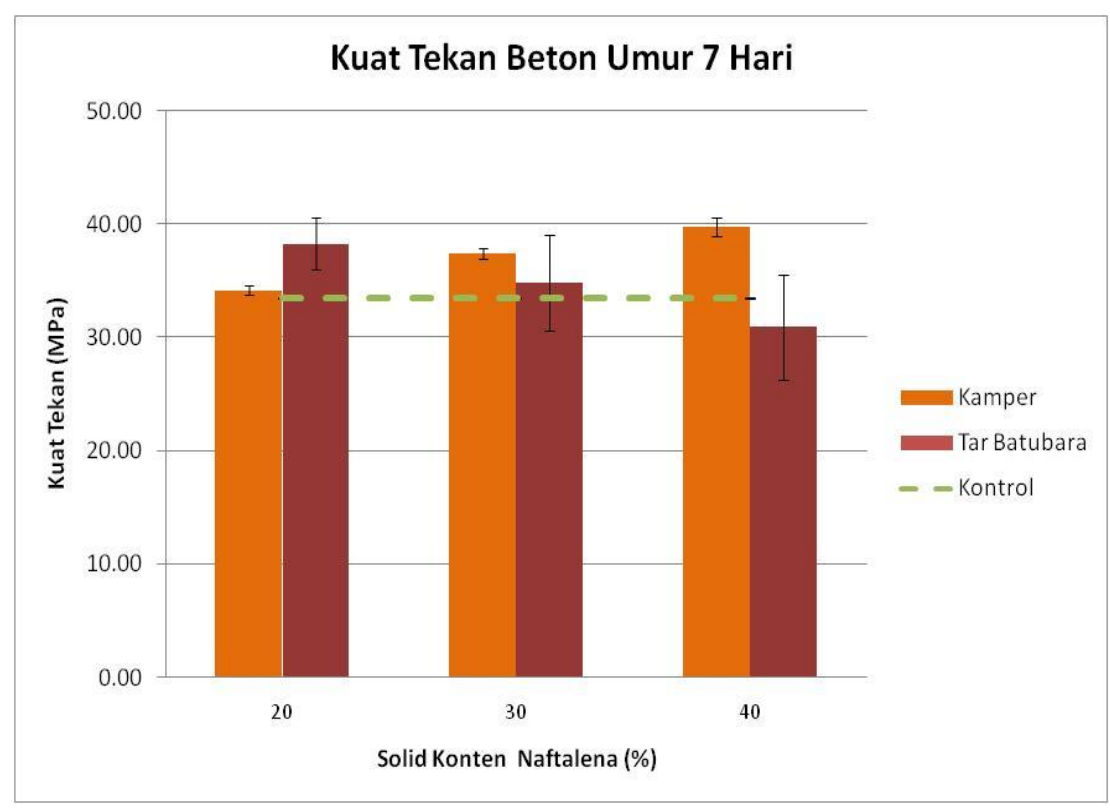

Picture 7 compressive strength 7 day

Source: Research Data

In the study of compressive strength of 7 days old concrete that is control concrete produces $33.53 \mathrm{MPa}$. Using camphor naphthalene that is a variation of $20 \%$ has a compressive strength of $34.20 \mathrm{Mpa}, 30 \%$ has a compressive strength of $37.40 \mathrm{Mpa}, 40 \%$ has a compressive strength of $39.80 \mathrm{Mpa}$. While naphthalene coal tar produces compressive strength, that is, the variation of $20 \%$ has a compressive strength of 38.30 $\mathrm{MPa}, 30 \%$ has a compressive strength of $34.90 \mathrm{MPa}, 40 \%$ has a compressive strength of $30.92 \mathrm{MPa}$.

\section{Compressive Strength Testing for 14 Days.}

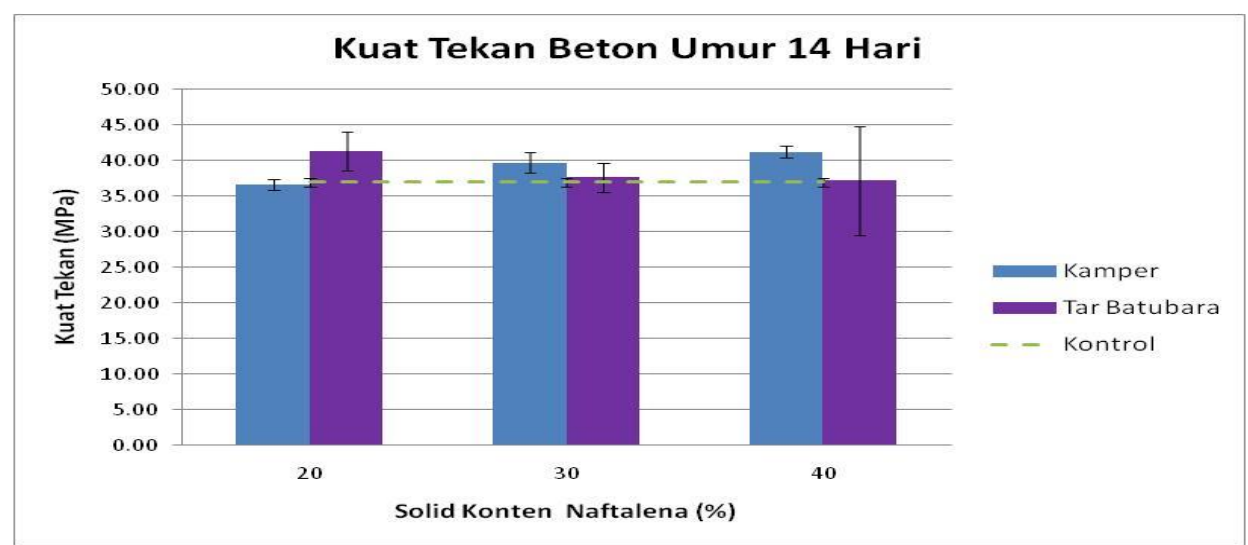

Picture 8 Compressive Strength Testing for 14 Days

Source: Research Data 


\section{Volume 03 Number 02 Maret 2020}

In the study of compressive strength of 7 days of age, the control concrete produced 36.97 MPa. Using camphor naphthalene that is a variation of $20 \%$ has a compressive strength of $36.63 \mathrm{MPa}, 30 \%$ has a compressive strength of $39.77 \mathrm{MPa}, 40 \%$ has a compressive strength of $41.26 \mathrm{MPa}$. While naphthalene coal tar produces compressive strength, that is, the variation of $20 \%$ has a compressive strength of $41.34 \mathrm{MPa}, 30 \%$ has a compressive strength of $37.65 \mathrm{MPa}, 40 \%$ has a compressive strength of 37.21 MPa.

\section{Compressive Strength Testing for 28 Days.}

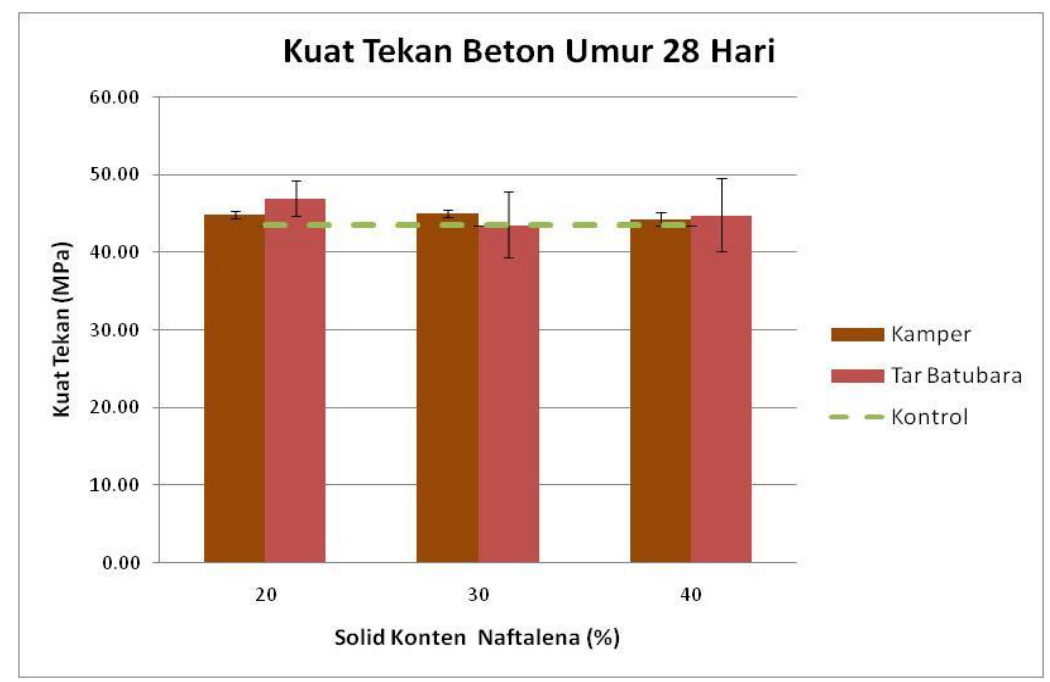

Picture 9 Compressive Strength Testing for 28 Days

Source: Research Data

In the research of 28 days the compressive strength of concrete that is control concrete produces $43.46 \mathrm{MPa}$. Using camphor naphthalene that is a variation of $20 \%$ has a compressive strength of $44.85 \mathrm{Mpa}, 30 \%$ has a compressive strength of $45.05 \mathrm{Mpa}, 40 \%$ has a compressive strength of $44.27 \mathrm{Mpa}$. While naphthalene coal tar produces compressive strength, that is, the variation of $20 \%$ has a compressive strength of 46.97 $\mathrm{MPa}, 30 \%$ has a compressive strength of $43.58 \mathrm{MPa}, 40 \%$ has a compressive strength of $44.83 \mathrm{MPa}$.

\section{CONCLUSION}

1. In this study the value of camphor slump is $40 \%$ and coal tar concrete is $30 \%$ higher which is $14 \mathrm{~cm}$ compared to other concrete and control concrete variations. With this, concrete using $40 \%$ camphor and $40 \%$ coal tar is easier to work with.

2. In this study the results of the density of concrete with $40 \%$ coal tar have the highest supply of $2356.7 \mathrm{~kg} / \mathrm{m} 3$.

3. Concrete using camphor $40 \%$ variation has the greatest absorption which is $1.29 \%$ compared to other variations and control concrete, while concrete using $20 \%$ coal tar has the greatest absorption which is $1.92 \%$ compared to other coal tar variations and control concrete .

4. For the age of 14 days concrete using camphor $40 \%$ and concrete using coal tar $20 \%$ has a compressive strength that is almost the same $12 \%$ higher than the control concrete. For the age of 28 days camphor concrete $30 \%$ has $3.7 \%$ higher than the control concrete and coal tar concrete $20 \%$ has $8.1 \%$ higher than the control concrete. 


\section{REFERENCES}

Badan Standarisasi Nasional. 2000. "SNI 03-2834 2000 :Tata Cara Pembuatan Rencana Campuran Beton Normal". Jakarta : Badan Standarisasi

Mulyadin, Iwan; Nadia, Nadia. Analisis Penggunaan Admixture Berbahan Dasar Naphthalene Terhadap Penggunaan Pasir Putih Dan Pasir Hitam Ditinjau Dari Setting Time. Konstruksia, 2012, 4.1.

Nadia, Nadia; Aprilianti, Seti. Analisis Pengaruh Beton Dengan Bahan Admixture Naphtalene Dan Polycarboxilate Terhadap Kuat Tekan Beton Normal. Konstruksia, 2012, 3.2

NASIONAL, Badan Standarisasi. Persyaratan beton struktural untuk bangunan gedung (SNI 2847: 2013). Jakarta: Standar Nasional Indonesia, 2013.

Prasetyo, Lukito. Pengaruh Variasi Gradasi Limbah Beton Sebagai Bahan Pengganti Agregat Terhadap Kuat Tekan. In: Prosiding Sentra (Seminar Teknologi Dan Rekayasa). 2019. P. 52-55

Simatupang, Partogi H.; Sir, Tri Mw; Kurniaty, Anna S. Pengaruh Substitusi Parsial Semen Dengan Abu Terbang Terhadap Karakteristik Teknis Beton. Jurnal Teknik Sipil, 2016, 5.2: 139-148

Tata, Arbain; Sultan, Mufti Amir; Sumartini, Sumartini. Pengaruh Penambahan Abu Sekam Padi Sebagai Campuran Bahan Baku Beton Terhadap Sifat Mekanis Beton. Sipil Sains, 2016, 6.11

TUMIWA, Brian; MANALIP, Hieryco; TAMBOTO, Winny J. Pemeriksaan Tegangan Lekat Antara Baja Dan Beton Dengan Kuat Tekan Beton 40 Mpa. Jurnal Sipil Statik, 2016, 4.1. 